Portland State University

PDXScholar

\title{
Cultivating (a) Sustainability Capital: Urban Agriculture, Eco-Gentrification, and the Uneven Valorization of Social Reproduction
}

Nathan McClintock

Portland State University, n.mcclintock@pdx.edu

Follow this and additional works at: https://pdxscholar.library.pdx.edu/usp_fac

Part of the Food Security Commons, and the Urban Studies and Planning Commons Let us know how access to this document benefits you.

\section{Citation Details}

McClintock, Nathan, "Cultivating (a) Sustainability Capital: Urban Agriculture, Eco-Gentrification, and the Uneven Valorization of Social Reproduction" (2017). Urban Studies and Planning Faculty Publications and Presentations. 168.

https://pdxscholar.library.pdx.edu/usp_fac/168

This Post-Print is brought to you for free and open access. It has been accepted for inclusion in Urban Studies and Planning Faculty Publications and Presentations by an authorized administrator of PDXScholar. Please contact us if we can make this document more accessible: pdxscholar@pdx.edu. 
Forthcoming, Annals of the American Association of Geographers 2018 Special Issue: Social Justice in the City

Accepted 9 February 2017

\title{
Cultivating (a) sustainability capital: Urban agriculture, eco-gentrification, and the uneven valorization of social reproduction
}

Nathan McClintock

Toulan School of Urban Studies and Planning, Portland State University

n.mcclintock@pdx.edu

\begin{abstract}
Urban agriculture (UA), for many activists and scholars, plays a prominent role in food justice struggles in cities throughout the Global North, a site of conflict between use and exchange values, and rallying point for progressive claims to the right to the city. Recent critiques, however, warn of its contribution to gentrification and displacement. The use/exchange value binary no longer as useful an analytic as it once was, geographers need to better understand UA's contradictory relations to capital, particularly in the neoliberal Sustainable City. To this end, I bring together feminist theorizations of social reproduction, Bourdieu's "species of capital", and critical geographies of race to help demystify UA's entanglement in processes of eco-gentrification. In this primarily theoretical contribution, I argue that concrete labor embedded in household-scale UA - a socially reproductive practice-becomes cultural capital that a Sustainable City's growth coalition in turn valorizes as symbolic sustainability capital used to extract rent and burnish the city's brand at larger scales. The valorization of UA occurs, by necessity, in a variegated manner; spatial agglomerations of UA and the eco-habitus required for its misrecognition as sustainability capital arise as a function of the interplay between rent gaps and racialized othering. I assert that eco-gentrification is not only a contradiction emerging from an urban sustainability fix, but is central to how racial capitalism functions through green urbanization. Like its contribution to eco-gentrification, I conclude, UA's emancipatory potential is also spatially variegated.
\end{abstract}

Key Words: capital, gentrification, social reproduction, sustainability fix, urban agriculture 
For many activists and scholars, urban agriculture (UA) serves as a rallying point for food justice, food sovereignty, and progressive claims to the right to the city across the Global North (Bradley and Galt 2014; Purcell and Tyman 2014). But while David versus Goliath standoffs between bulldozers and gardeners, use and exchange value, may have once defined UA in the public imagination, rooftop gardens growing salad greens for farm-to-table restaurants are now perhaps more representative. Urban agriculture, which has come to symbolize both the environmental values undergirding urban sustainability efforts and the "local" and "artisanal" so cherished by foodies (Johnston and Baumann 2014), is also often the fruit of an "unexpected romance" (Holt 2015) between urban agriculturists and real estate developers. Critics both within and outside academia (Quastel 2009; Crouch 2012) have thus begun to scrutinize its role as "an attractive place holder on the road to gentrification" (DeLind 2015, 3).

Indeed, UA is often a temporary land use on vacant or devalued sites awaiting the next wave of investment (McClintock 2014), spaces Walker $(1978,32)$ dubbed the "lumpengeography" of capital. But where gardens throughout history cropped up opportunistically as a coping strategy in the face of food and wage insecurity (Lawson 2005; McClintock 2010), they now more often signal the transformation of these same devalued neighborhoods (see Figure 1). A clear connection exists between the gentrification of these lumpengeographies and the proliferation of restaurants and grocery stores that capitalize on the mainstreaming of "foodie" culture and the value it places on local, organic consumption (Burnett 2014; Anguelovski 2015). But scholars are only beginning to examine how urban food production is entangled in processes of gentrification and capital accumulation, more broadly.

While earlier literature described UA in terms of gardens versus development and the incommensurability of these two use values (Schmelzkopf 2002), newer work reveals that gardening is actually quite commensurable with the market logics of development (Quastel 2009; Walker 2016) and, particularly in progressive urban centers, contributes to a "sustainability fix"- the "selective incorporation of environmental goals" (While, Jonas, and Gibbs 2004, 552) by growth coalitions of developers, consulting firms, non-profits, planners, and policymakers attempting to balance the entrepreneurial imperative of economic growth and public demands for ecological regulation. But while a sustainability fix may blur the lines between environmental stewardship and economic growth, it is nevertheless a fix, temporary and prone to fracture. Gentrification - "the production of space for progressively more affluent users" (Hackworth 2002, 815)_or, more specifically, ecogentrification resulting from "the implementation of an environmental agenda driven by an environmental ethic" (Dooling 2009, 41) - is perhaps the central contradiction arising from an urban sustainability fix. A growing body of scholarship reveals how green infrastructure fuels rising property values and rents, and how green space becomes commodified for consumption (Pearsall 2010; Checker 2011; Rosol 2013; Gould and Lewis 2016), generating surplus value not only for developers, rentiers, and the growth coalitions to which they belong, but also for global

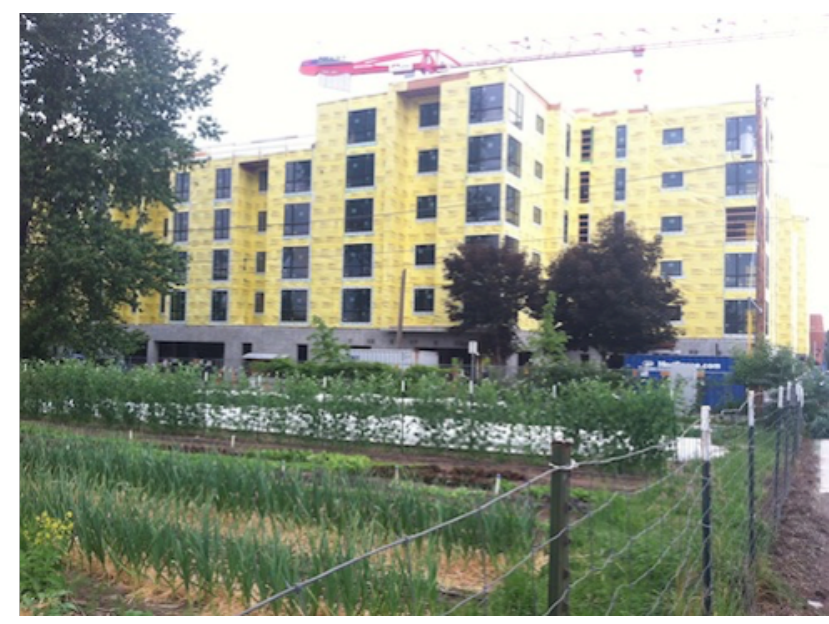

Figure 1. A market garden surrounded by new-build condos in a rapidly gentrifying area of Portland, Oregon. 
finance capital (Knuth 2016). As these scholars have demonstrated, sites of eco-gentrification are also becoming central sites of contestation in the Sustainable City (Lubitow and Miller 2013; Pearsall and Anguelovski 2016).

The use/exchange value binary thus no longer as useful an analytic as perhaps it once was, there is significant work to be done to clarify the dynamics by which UA contributes to capitalist accumulation in the neoliberal green city. Moreover, how non-commodified forms of UA actually produce value - particularly under racial capitalism (Robinson 2000; Pulido 2016) begs closer examination. To this end, I attempt to break some new ground with this paper, not by shoring up the jejune claim that UA is a bellwether of gentrification, but by sketching out a theory of UA's uneven valorization within racialized processes of capitalist urbanization. I work through UA's valorization process in two steps. First, I situate UA within the realm of social reproduction, drawing on Bourdieu to explain how UA, as a socially reproductive practice, becomes cultural capital that the Sustainable City's "green growth machine" (Gould and Lewis 2016, 35-36) mobilizes as symbolic sustainability capital, both to extract rent and burnish the city's brand at larger scales. Second, I describe how such valorization occurs, by necessity, in a spatially variegated manner. Agglomerations of both UA and the eco-habitus required for its misrecognition as cultural capital, I assert, arise as a function of the interplay between ground rent and racialized othering. Eco-gentrification, therefore, is not only a contradiction emerging from an urban sustainability fix, but is fundamental to how racial capitalism works through green urbanization. I conclude by reflecting very briefly on UA's emancipatory potential.

\section{Valorizing social reproduction through misrecognition}

De-centering orthodox readings of Marx, which define value as the "abstract human labor objectified or materialized" in a commodity as measured by the socially necessary labor time required to produce it (Marx 1976, 129), feminist political economists and geographers have recast the production of value to encompass the entirety of the production/reproduction dialectic (Dalla Costa and James 1972; McDowell 1999; Federici 2004; Mitchell, Marston, and Katz 2004; Bezanson and Luxton 2006; Meehan and Strauss 2015). The capitalist mode of production, from this perspective, does not require "commodities all the way down" (Fraser 2014), nor does it simply subsume other modes; rather, it relies on them for its own reproduction, transforming them (or not) in the process. As Henderson $(1998,78)$ observes, "the social relations of production at any point in time will lie along a continuum" of capitalist subsumption. Moreover, individuals are enmeshed in multiple relations at once, some of which are more capitalist than others (Gibson-Graham 2006; Meehan and Strauss 2015).

Most labor dedicated to UA in the Global North lies at the reproductive end of such a continuum. With the exception of a small cadre of market gardeners, urban agriculturalists (a majority women) for the most part only produce food for household use. Scholars of agrarian political economy have argued that the fruits of the home gardener's labor serve as a subsidy to capital, where self-provisioning lowers the cost of living (i.e., social reproduction), thus lowering the real cost of labor power and thereby justifying lower wages paid, ultimately lowering the cost of production (McClintock 2010; Minkoff-Zern 2014; Weissman 2015). A household-scale subsidy, from this perspective, would produce value only when aggregated across the workforce. While more than a third of the US population engages in food production (National Gardening Association 2014), the impact of homegrown produce on grocery costs is nevertheless minimal (CoDyre, Fraser, and Landman 2015). I argue, therefore, that another kind of valorization of 
social reproduction is taking place, where the practice of UA contributes to accumulation not only by subsidizing the cost of labor, but also symbolically, as I now explain.

In theorizing social space, Bourdieu (1986) describes how relative stocks of different "species" of capital confer social status or "distinction" within a given social field. While economic capital is defined in monetary terms, cultural capital includes a combination of values and tastes (the embodied state), cultural goods (the objectified state), and qualifications or valorizations (the institutionalized state). Recognizing these various forms allows us to "reintegrate and reconceive use value within circuits of cultural and economic capital" (BeasleyMurray 2000, 107), while "enabling us to see consumption outside the workplace as likewise production and not simply as need-driven utility" (113). When "perceived and recognized as legitimate" (Bourdieu 1989, 17), these forms of cultural capital serve as symbolic capital that can be leveraged to foster accumulation of economic capital. Bourdieu's species of capital therefore allow us to place social reproduction squarely within production, much as feminist reworkings of political economy do, rather than sidelining it as part of a consumption fund that subsidizes capital accumulation (e.g. Harvey 1989).

I maintain that while commercial UA generates substantial exchange value in the Sustainable City through commodity production, the valorization of socially reproductive forms of UA generates even more surplus value-when mobilized as a particular symbolic form of cultural capital I call sustainability capital. In progressive, green cities, gardening carries a certain cachet at the household and neighborhood scales; as a performative act, it signals an awareness of and adherence to environmental values (Naylor 2012; Lebowitz and Trudeau 2016). But UA holds no intrinsic value as cultural capital, so how is it valorized?

Following Bourdieu, valorization of UA as symbolic capital requires its misrecognition as cultural capital in both objectified and embodied forms, i.e., the garden and the gardener. ${ }^{1} \mathrm{~A}$ "symbolic logic of distinction" marks the practitioner from others living less sustainably, for "any given cultural competence (e.g., being able to read in a world of illiterates) derives a scarcity value from its position in the distribution of cultural capital and yields profits of distinction to its owner" (Bourdieu 1986, 245). Misrecognition of UA, I submit, depends on the predominance of an eco-habitus, or set of practices and dispositions undergirded by green values. A "re-articulation of the field of high-class consumption, fostered by a more general social valorization of environmental consciousness" (Carfagna et al. 2014, 3), an eco-habitus also fuses concern for environmental sustainability with the "valorization of the local" and "revalorization of manual labor" (15) that undergird foodie emphases on "quality, rarity, organic, hand-made, creativity, and simplicity" (Johnston and Baumann 2014, 3).

When and where an eco-habitus predominates, it is therefore use value itself-rather than an abstracted form of value based on socially necessary labor time-that is valorized via misrecognition. While the latter form of value "grasps only immediate time, time as present" (Postone 1978, 770), use value is a function of "the accumulation of past knowledge and labor time which ... finds no expression in the value-determined forms of appearance" (ibid.). Rather than a measure of the socially necessary labor time required to till, sow, tend, and harvest a garden, UA's symbolic value is instead derived from the concrete time and labor spent by an urban agriculturalist both coaxing use values from the soil and acquiring the skills, practices, dispositions - mastering the "feel for the game" (Bourdieu 1998, 98) - that allow her to do so.

With the rare exception of the gardener selling produce or teaching workshops, however, urban agriculturalists themselves do not "cash out" this cultural capital. Rather, rentiers, boosters, and financiers exchange these "free gifts of culture" (Stehlin 2016, 483) for economic capital at 
different scales. Urban growth coalitions mobilize this symbolic capital to competitively promote a city's reputation as a hotbed of sustainability and livability in hopes of attracting new investment, skilled labor, and green consumers, just as developers exchange it at the neighborhood scale for differential ground rent. At the global scale, these concrete transactions become "a collection of abstract, intangible, and interchangeable assets" (Knuth 2016, 628) that are themselves commodified, generating profits for financial institutions and shareholders.

For example, in Portland, Oregon - among the "top ten cities in the US for urban farming" (Renner 2016) - a growth coalition of municipal agencies, non-profits, developers, and other businesses tout the city's green amenities (including UA) via tours, conferences, exchanges, and other forms of "policy boosterism" (McCann 2013) that burnish Portland's international renown as a paradigmatic Sustainable City, attracting both investors and the highly educated consumers willing to work for lower real wages (relative to other metropolitan areas) in exchange for the green lifestyle that Portland has to offer (Jurjevich and Schrock 2012). As the Director of Portland's Bureau of Planning and Sustainability admits, sustainability is entrepreneurial as much as it is rooted in environmental values:

We're not doing it just to be altruistic. Part of the reason we're doing a lot of this is there's money to be made, to be crass ... And most of these things are things we want to do to create better, healthier places, anyway. But by doing that, you create a place where people want to live and have businesses. (quoted in Smith 2012)

In the case of non-commercial UA, then, surplus value accrued at these larger scales is extracted from household-scale social reproduction, and a garden's valorization as economic capital depends less on the habitus of the individual gardener and more on its wider misrecognition as cultural capital and eventual mobilization as symbolic capital at these larger scales. As I argue in the next section, the process of misrecognition - and valorization across scales - is fundamentally spatial, both arising from and contributing to racialized processes of uneven development.

\section{Uneven valorization, rent, and the racialized re-coding of urban space}

For misrecognition to occur, two types of spatial agglomeration are necessary. First, there simply must be enough UA happening in a given place to be noticed; only when multiple households practice UA does it become visible enough to accrue any real symbolic value. Second, there also has to be a sufficient aggregation of people with similar values and tasteswith "identical categories of perception and appreciation" (Bourdieu 1998, 100)—who perceive UA as a marker of distinction, more common in cities such as Vancouver or Portland than in cities where UA might still be viewed as backward (Naylor 2012; McClintock et al. 2016). In other words, an eco-habitus must be sufficiently predominant within an urban populationwhether spatially clustered, or networked via affinity groups and social media (see Tarr 2015) to impact the various individuals and institutions (e.g., government agencies, non-profits, media, real estate markets) that mediate cultural capital's symbolic exchange value. ${ }^{2}$

Urban agriculture's ability to function as sustainability capital is therefore spatially variegated. Where there are agglomerations of gardens and chicken coops and of eco-minded residents who misrecognize these agglomerations as cultural capital, UA gains symbolic value, 
generating both profits of localization for those in close spatial proximity, and profits of position for those whose labor is misrecognized as cultural capital (Bourdieu 2000, 126-127). Conversely, where gardens or eco-minded individuals are more dispersed, disconnected, or distant from the core, their relative distance limits the potential aggregative capacity to convert social reproduction into sustainability capital. Likewise, where an eco-habitus does not predominatethat is, where environmental concerns do not drive food production or, alternately, where existing gardens are perceived as backward or unsightly-UA accrues little or no value as cultural capital. Even if practiced widely, it essentially remains invisible at the urban scale. Indeed, the UA practices of longtime residents, often cultivated for food security or cultural reasons, are often simply overlooked (Cheung 2016; Reynolds and Cohen 2016); in other cases, they are actually undermined by new restrictions on garden forms (e.g., trellises, greenhouses, coops) or increased fees for community gardens plots, for example (Eizenberg 2012; Ghose and Pettygrove 2014).

I further maintain that for valorization to occur, such spatial variegation is necessary rather than contingent. As Stehlin and Tarr (2016, 14-15) explain, "creating spaces that are unusually livable can be completely congruent with property-based accumulation, which depends on qualitative differences between spaces that prompt flows of capital between them." Labor-intensive practices, whether socially reproductive or artisanal, have symbolic value - and can therefore contribute to an urban sustainability fix - only when they can help distinguish spaces deemed "sustainable" or "livable" from those less so. Put simply, the symbolic value of UA depends to a certain extent on its scarcity value. In the Sustainable City, a raised bed in the front yard (see Figure 2) distinguishes the eco-minded gardener from the typical North American, whose chemically fertilized lawn has come to signify unsustainable living. In aggregate, these gardens distinguish a city's hip, livable, green neighborhoods - or the promise of those to come - from the anomie and sprawl of mainstream suburbia, and from the not-yet-gentrified lumpengeographies of the post-industrial inner-core and devalued inner-ring suburbia. Urban agriculture's symbolic value (and its misrecognition as such) is tied to these qualitative differences, and therefore to the perpetual seesawing motion of capital that creates them (Smith 2008).

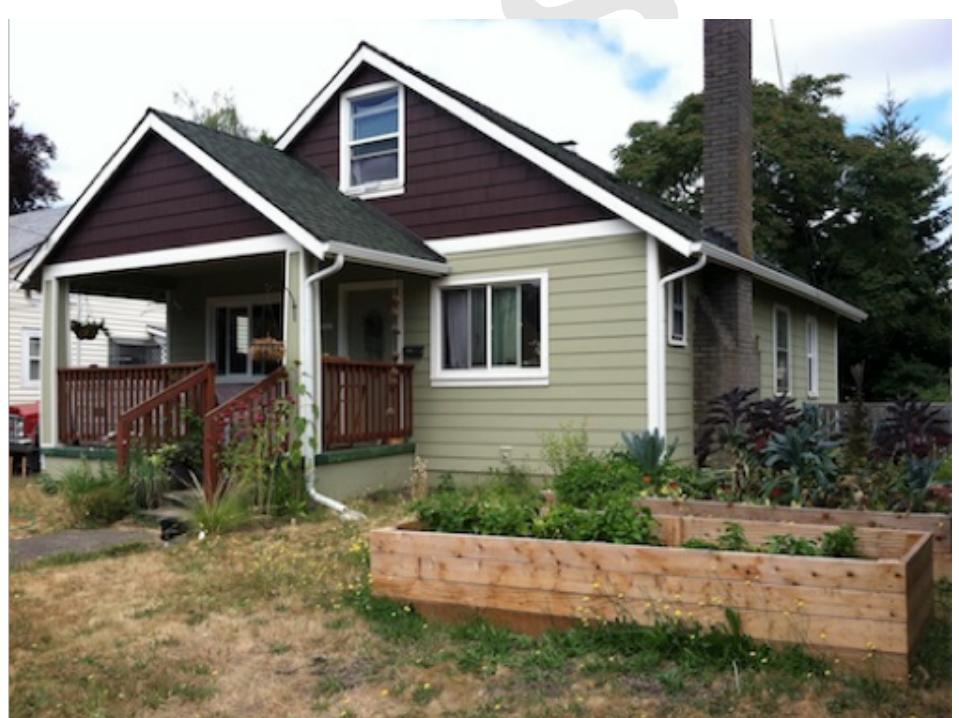

Figure 2. A front yard garden in a gentrifying neighborhood of inner Portland.
For the better part of four decades, the rent gap (Smith 1979) between capitalized and potential ground rent - between actual market prices and unrealized market potential-has been the linchpin of production-side explanations of gentrification, and of uneven urban development more broadly (Harvey 1989; Hackworth 2002). Moving beyond the false dichotomy of the production/consumption debate, however, requires recognizing that rent gaps open and close in dialectical tension with the movement of more affluent and educated, and predominantly white 
populations into devalued neighborhoods (Slater 2006). With new arrivals come new forms of habitus and attendant changes in amenity and commodity consumption, which, in aggregate, raise potential ground rents, attracting investors. The budding agglomeration's gravitational pull on additional gentrifiers depends on the availability of cheap housing (or land) at first, but eventually on the suite of amenities (including UA) making a name for the neighborhood (Zukin 1987; Smith 1996). Longtime residents may garden, but only when enough newcomers practice UA in way that is visible - in their front yards, community garden plots, or vacant lots - does UA function as an amenity that signals to future gentrifiers and investors that the neighborhood is on the road to being livable and green. Agglomerations of UA, then, emerge disproportionately in those areas where a rent gap can be closed.

Our research in Portland illustrates such a pattern (McClintock et al. 2016). ${ }^{3}$ Front yard gardens, visible and performative, are disproportionately concentrated in inner Portland's singlefamily residential neighborhoods, particularly in those areas deemed most "livable" given their walkability and proximity to green amenities, as well as in neighborhoods that have been gentrified or where gentrification is underway (see Figure 3). A commitment to sustainability drives UA here; a whopping 91 percent of front yard gardeners - overall more affluent than the surrounding populationare motivated by a desire "to live in a more environmentally sustainable way." Clusters of backyard gardens, on the other hand, exist throughout the city, including in low-income, highly diverse East Portland, where gardeners are less affluent than the surrounding population and are motivated more by concerns over food security. Misrecognized as sustainability
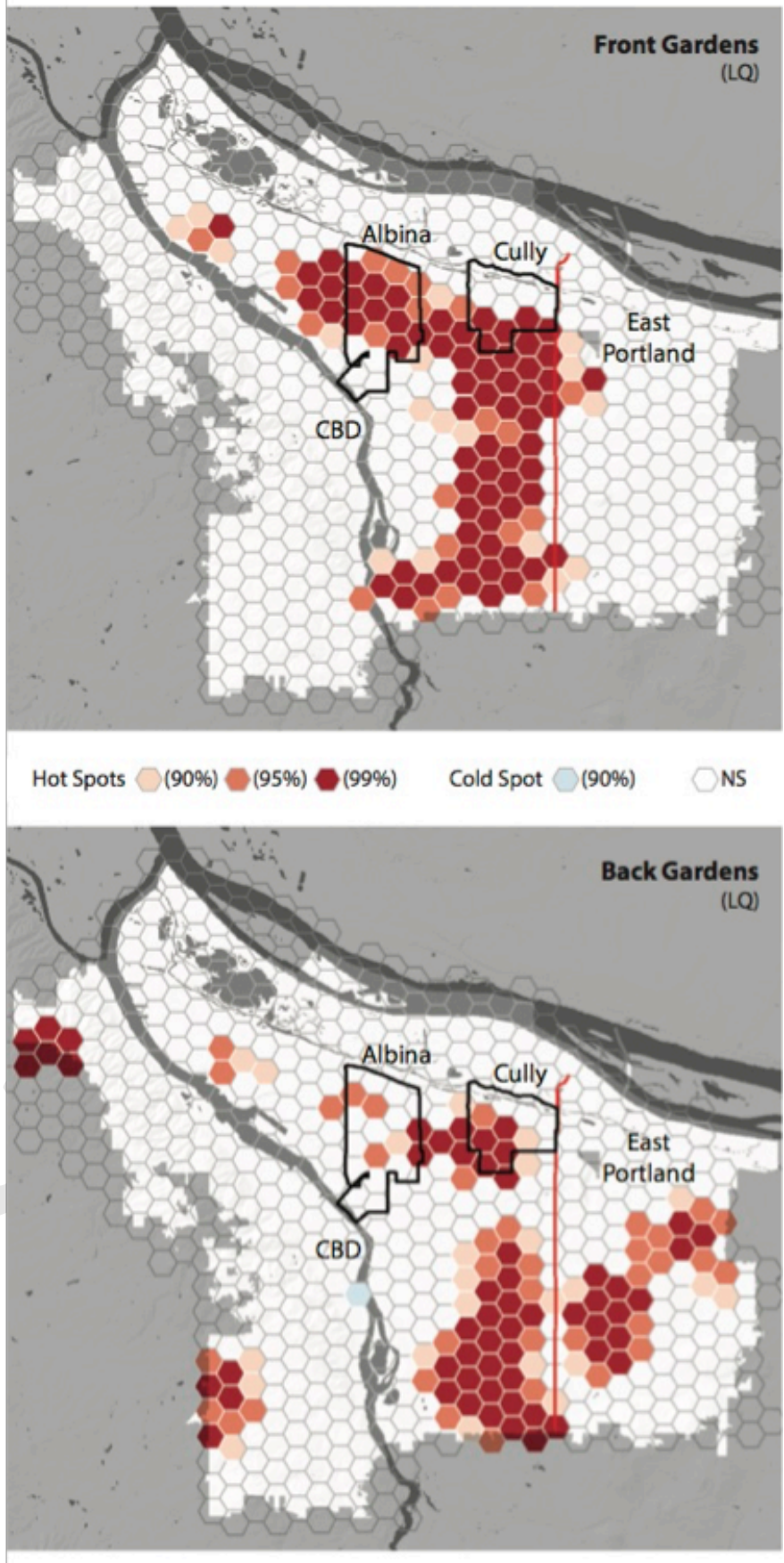

Figure 3. Hot-spot analysis of front gardens (top) and back gardens (bottom) in Portland, based on a location quotient calculated for each $1.52 \mathrm{~km}^{2}$ hexagon. Front yard gardens, visible and performative, are concentrated in the city's "livable" inner core, including Albina - ground zero of gentrification - and Cully, a neighborhood in the early stages of gentrification and known for its vibrant urban agriculture scene. Clusters of less-visible backyard gardens exist in these same areas, but can also be found in lowerincome East Portland. Map by Dillon Mahmoudi, data source: McClintock et al. 2016. 
capital by affluent, predominately white, eco-minded residents, inner Portland's home gardens are valorized as economic capital by the city's green growth coalition at larger scales, contributing to higher home values at the city scale, and to Portland's brand as a Sustainable City nationally and globally. Conversely, gardens in the lumpengeography of East Portland - an area that ranks lowest in terms of livability by all city metrics (Goodling, Green, and McClintock 2015) - remain largely invisible, their use value unvalorized beyond the household scale. A quick scan of real estate listings containing the term "garden beds", for example, revealed twenty-nine listings, all but four located in Portland's inner core or the newly gentrifying areas of East Portland just east of $82^{\text {nd }}$ Avenue (Zillow 2016). Listings with the term "urban farm" were likewise situated in gentrification hotspots such as Cully, the most ethnically diverse neighborhood in the state. While longtime residents have gardened in Cully's spacious lots, its reputation as a UA hotspot rests more on the successes of younger (mostly white) newcomers, several of whom are engaged in highly visible, commercial UA. One market gardener recalls looking for land here: "So I drove down here and started cruising around ... I'd just heard that this is the urban farming, or homesteading district of Portland."4 As the gentrification frontier pushes eastward past $82^{\text {nd }}$ Avenue, a critical agglomeration of old and new UA — and the habitus necessary to misrecognize it as sustainability capital - is sure to follow suit.

But Pulido $(2016,4)$ observes that just as capital depends on spatial unevenness, "human difference is essential to the production of differential value." The "racialization of space and spatialization of race" (Lipsitz 2007, 12) are therefore codetermined (Pulido 2000; Woods 2000; Gilmore 2002; Barraclough 2009). Recent scholarship further clarifies how a sustainability fix articulates with the larger racial project of capitalist accumulation and illustrates McKittrick's $(2011,951)$ assertion that "the process of uneven development calcifies the seemingly natural links between blackness, underdevelopment, poverty, and place." Situating gentrification's pioneer imaginary (see Smith 1996) within persistent settler colonial logics of dispossession, Safransky $(2014,238)$ describes how investments in green infrastructure in Detroit turn on "frontier narratives," wherein potential redevelopment sites are described as "empty and underutilized ... awaiting inhabitants and transformation, [thus] nullifying existing ways of life." Similarly, Dillon $(2014,1214)$ describes how the othering of urban spaces - as "under-utilized, economically unproductive lands" - that precedes redevelopment is tightly bound to the discursive and material ghettoization of surrounding neighborhoods of color. The characterization of one space as sustainable, green, or livable - in the media, in advertising, in government reports, and in everyday speech - thus renders another unlivable or "uninhabitable" (McKittrick 2006, 128-133), a swath of "urbs nullius" (Coulthard 2014, 176) awaiting pioneer (re)settlement (Blomley 2003; Safransky 2014). It becomes clear, then, that eco-gentrification is not only a contradiction emerging from an urban sustainability fix, but is central to how racial capitalism works through green urbanization.

At its core, distinguishing the livable from the uninhabitable-indeed, delimiting the lumpengeography of capital and spatial contours of the rent gap-depends on "shared cultural ideals and moral geographies based on a romance with pure spaces" (Lipsitz 2007, 12). Such conceptions of purity have long underwritten eco-habitus and can be implicated in processes of racial othering (Cronon 1996; Moore, Pandian, and Kosek 2003; Finney 2014). Alternative agrifood practices, too, with their roots in the environmental movement, invoke such purity discourse. An explicit rejection of the industrial agri-food system often turns on the demonization of certain foods and body types (Guthman 2011), while appealing to agrarian imaginaries that efface people of color (Carlisle 2014). Moreover, many food system activists trumpet consumption- 
oriented solutions that require disposable income, e.g., "voting with your fork" by purchasing unprocessed, organic vegetables at a farmers market (Alkon and McCullen 2011). Other solutions require free time, such as volunteering with a non-profit garden project (Pudup 2008). Even the most well-intentioned food justice activists are culpable of othering via their missionary zeal to "bring good food to others" (Guthman 2009). The embrace of such purity narratives, a "feel for the game", and the "viscosity" (Slocum 2007) or attraction of white bodies sharing an eco-habitus together contribute to the coding of these spaces as white and to the alienation of people of color (Henson and Munsey 2014; Ramírez 2015).

Ground rent, eco-habitus, and racial viscosity thus work together to render UA spaces as white, and in so doing, contribute to the racial re-coding of urban space at eco-gentrification's frontier, where a succession of racially coded descriptors marks the settling of the uninhabitable landscape: "sketchy" gives way to "up-and-coming" and "hip", and eventually to "familyfriendly", "livable", and "green". Both an amenity that attracts foodie activists and hipster pioneers and a manifestation of their eco-habitus, UA plays an important role in distinguishing "new development, rising home values, and a whiter residential population" from a neighborhood's "racially marginalized past" (Dillon 2014, 1211). In the words of one young white urban farmer in Vancouver, "If there are community gardens or a street that looks like people are growing food on it, I think for the people I know, that plays into the 'Oh, this is upand-coming' or 'It's okay to live here' type thing.",

Conversely, for longtime residents of these neighborhoods, lower income and often nonwhite, the new gardens symbolize their impending fate. An African American business leader in Portland laments, "I knew black people were fucked as soon as I saw the bike lanes. That's when we knew we weren't welcome here anymore." His colleague adds: "And the community gardens. That's another bad sign for the African American community. We always gardened. We always shared our gardens and our food. We didn't need 'community gardens'. That's a white invention" (quoted in Hern 2016, 10). At the same time, their own histories of gardening, canning, and other artisanal foodways - like the spatial clusters of UA found in East Portland and other "uninhabitable" areas devoid of eco-habitus - are rendered invisible by media attention lavished on young, white, and affluent foodies working in particularly photogenic, often capital-intensive gardens, on rooftops and other high-profile, performative locations (Reynolds and Cohen 2016). Given the agglomerations of white bodies and their underlying eco-habitus, these performances, while functioning as symbolic capital to increase ground rents and burnish the entrepreneurial Sustainable City's brand, can alienate and ultimately exclude. Describing a nearby community garden, an African American community organizer in Portland avers, "You ain't seeing any people of your kind, and you're kinda like, 'Oh, this ain't for me.'",6

\section{Conclusion}

My goal here, rather than viewing UA within the context of pitched battles over conflicting use values between gardeners and bulldozers, has been to theorize its valorization as capital within the eco-gentrification process itself, which I see as one of the primary urban manifestations of racial capitalism. I want to underscore that gardens and other forms of food production alone do not drive gentrification. Rather, as I've argued here, their uneven valorization is socio-spatially dependent on both the agglomeration of eco-habitus and the racialized historical-geographical factors giving rise to rent gaps in particular neighborhoods. The growing agglomeration of white bodies in formerly "uninhabitable" spaces gives a spatial dimension to the eco-habitus that misrecognizes concrete time and labor invested in UA as 
sustainability capital. Moreover, a post-political, colorblind discourse of sustainability obscures the resulting whitening of urban space, but nevertheless functions tacitly within the larger racial project of gentrification arising from an urban sustainability fix. Understanding UA's valorization this way reveals how practices of social reproduction can contribute to such a fix, and "connects the discursive construction of race to the structural, material, and corporeal production of white racial hegemony" (Bonds and Inwood 2016, 720), especially in green cities where white people pride themselves on their liberal or progressive values - and their colorblindness.

Notwithstanding its subsumption by green entrepreneurial logics, however, social reproduction is also a sphere in which political organizing can occur, as feminist geographers have long asserted (Mitchell, Marston, and Katz 2004; Gibson-Graham 2006). The everyday space of non-capitalist UA can thus serve as a potential site of change, a rallying point for social justice and self-determination (White 2011; Reynolds and Cohen 2016). Indeed, the threat to community gardens has mobilized diverse, cross-class coalitions in the past (Staeheli, Mitchell, and Gibson 2002; Irazábal and Punja 2009). Eco-gentrification, too, in dialectical fashion, sows the seeds of resistance (Pearsall and Anguelovski 2016; Safransky 2016; McClintock, Miewald, and McCann forthcoming), and the presence of community, collective, and commercial gardens, old and new, led by people of color in gentrifying communities offers a hopeful example of UA serving as a tool for racial justice, empowerment, and economic development (White 2011; Ramírez 2015; Pearsall and Anguelovski 2016; Reynolds and Cohen 2016; Sbicca 2016), and helping to resist the processes I've described in this article.

But like its contribution to eco-gentrification, UA's emancipatory potential arguably also differs across time and space, for it is in the lumpengeography of the Sustainable City - where an eco-habitus has not yet taken hold - that UA resists subsumption by green entrepreneurial logics. Foregrounding already-existing gardens in such spaces (those clusters in East Portland, for example) is one simple but crucial way for scholars, journalists, and activists alike to unsettle the disproportionate misrecognition of eco-oriented, hipster-led UA as sustainability capital. Reynolds and Cohen (2016), for example, take stock of dozens of UA initiatives led by people of color in New York City and beyond, emphasizing the radical nature of their work, as well as the real need for material support to keep it going. Highlighting and honoring these invisible gardens - and, when possible, providing material support-also serves as an entry point for understanding eco-gentrification within the broader context of white supremacy and the settler colonial present, a necessary prerequisite, I would argue, for fostering and strengthening alliances with activists engaged in a wider range of social and racial justice movements.

\section{Acknowledgements}

I am grateful to the many graduate students and research assistants whose labor helped bring this research to fruition: Dillon Mahmoudi, Mike Simpson, Erin Goodling, Jamaal Green, Amy Coplen, Anthony Levenda, and Jacinto Santos. Warm thanks also to Eugene McCann and Christiana Miewald for helping me take it in new directions, and to Geoff Mann, Harold Perkins, Nathan Sayre, Evan Weissman, and audience members at the Tampa, Chicago, and Vancouver meetings of the American Association of Geographers and Canadian Association of Geographers for their thoughtful feedback on earlier versions. Finally, I'm grateful to John Stehlin, Alex Tarr, and two anonymous reviewers for their close readings and incisive comments, all of which strengthened the final version of the manuscript. All errors are entirely my own. 


\section{Notes}

${ }^{1}$ Misrecognition for Bourdieu speaks to the arbitrary nature of assigning value to something, rather than implying flawed or mistaken recognition.

${ }^{2}$ While Bourdieu saw the state as the "central bank of symbolic credit" (Beasley-Murray 2000, 115) mediating the valorization of the various forms of capital, a range of institutions are today involved in the valorization of the concrete time invested in cultivating cultural capital. Given the broader neoliberal context of state retrenchment and attendant entrenchment of market logics through privatization and public-private partnerships, the private sector plays a growing role in the misrecognition of institutionalized cultural capital (see Lave 2012). Institutional recognition for UA (e.g., master gardener certification) continues to play an important role in misrecognizing UA as sustainability capital, but the state is hardly the sole arbiter.

${ }^{3}$ My research assistants and I have been conducting mixed-methods research (including mapping, spatial analysis, mail surveys, interviews, media analysis, and archival work) in Portland for the past five years (Goodling, Green, and McClintock 2015; McClintock and Simpson 2016; McClintock et al. 2016). An ongoing relational comparative study of UA policy and practice in Portland and Vancouver builds on this work (McClintock, Miewald, and McCann forthcoming).

${ }^{4}$ Interview with the author, 1 Sep 2015.

${ }^{5}$ Interview with the author, 14 Oct 2016.

${ }^{6}$ Interview with the author, 11 Aug 2016. 


\section{References}

Alkon, A. H., and C. G. McCullen. 2011. Whiteness and farmers markets: Performances, perpetuations ... contestations? Antipode 43 (4):937-959.

Anguelovski, I. 2015. Healthy food stores, greenlining and food gentrification: Contesting new forms of privilege, displacement and locally unwanted land uses in racially mixed neighborhoods. International Journal of Urban and Regional Research 39 (6):1209-1230.

Barraclough, L. R. 2009. South Central Farmers and Shadow Hills homeowners: Land use policy and relational racialization in Los Angeles. The Professional Geographer 61 (2):164-186.

Beasley-Murray, J. 2000. Value and Capital in Bourdieu and Marx. In Pierre Bourdieu: Fieldwork in Culture, eds. N. Brown and I. Szeman, 100-119. Lanham, MD: Rowman \& Littlefield.

Bezanson, K., and M. Luxton. 2006. Social Reproduction: Feminist Political Economy Challenges Neo-Liberalism. Montreal: McGill-Queen's University Press.

Blomley, N. 2003. Unsettling the City: Urban Land and the Politics of Property. New York: Routledge.

Bonds, A., and J. Inwood. 2016. Beyond white privilege: Geographies of white supremacy and settler colonialism. Progress in Human Geography 40 (6):715-733.

Bourdieu, P. 1986. The Forms of Capital. In Handbook of Theory and Research for the Sociology of Education, ed. J. Richardson, 241-258. Westport: Greenwood. 1989. Social space and symbolic power. Sociological Theory 7 (1):14-25. 1998. Practical Reason: On the Theory of Action. Palo Alto: Stanford University Press. ed. 2000. Site Effects. In The Weight of the World: Social Suffering in Contemporary Society, 123-129. Stanford: Stanford University Press.

Bradley, K., and R. E. Galt. 2014. Practicing food justice at Dig Deep Farms \& Produce, East Bay Area, California: Self-determination as a guiding value and intersections with foodie logics. Local Environment 19 (2):172-186.

Burnett, K. 2014. Commodifying poverty: gentrification and consumption in Vancouver's Downtown Eastside. Urban Geography 35 (2):157-176.

Carfagna, L. B., E. A. Dubois, C. Fitzmaurice, M. Y. Ouimette, J. B. Schor, M. Willis, and T. Laidley. 2014. An emerging eco-habitus: The reconfiguration of high cultural capital practices among ethical consumers. Journal of Consumer Culture 14 (2):158-178.

Carlisle, L. 2014. Critical agrarianism. Renewable Agriculture and Food Systems 29 (2):135-145.

Checker, M. 2011. Wiped out by the "greenwave": Environmental gentrification and the paradoxical politics of urban sustainability. City \& Society 23 (2):210-229.

Cheung, C. 2016. Meet East Vancouver's original urban farmers. Vancouver Courier. http://www.vancourier.com/news/meet-east-vancouver-s-original-urban-farmers1.2320486 (last accessed 17 January 2017).

CoDyre, M., E. D. G. Fraser, and K. Landman. 2015. How does your garden grow? An empirical evaluation of the costs and potential of urban gardening. Urban Forestry \& Urban Greening 14 (1):72-79.

Coulthard, G. S. 2014. Red Skin, White Masks: Rejecting the Colonial Politics of Recognition. Minneapolis: University of Minnesota Press.

Cronon, W. 1996. The trouble with wilderness: Or, getting back to the wrong nature. Environmental History 1 (1):7-28. 
Crouch, P. 2012. Evolution or gentrification: Do urban farms lead to higher rents? Grist. http://grist.org/food/evolution-or-gentrification-do-urban-farms-lead-to-higher-rents/ (last accessed 1 November 2012).

Dalla Costa, M., and S. James. 1972. The Power of Women and the Subversion of Community. Bristol: Falling Wall Press.

DeLind, L. B. 2015. Where have all the houses (among other things) gone? Some critical reflections on urban agriculture. Renewable Agriculture and Food Systems 30 (Special Issue 01):3-7.

Dillon, L. 2014. Race, waste, and space: Brownfield redevelopment and environmental justice at the Hunters Point shipyard. Antipode 46 (5):1205-1221.

Dooling, S. 2009. Ecological gentrification: A research agenda exploring justice in the city. International Journal of Urban and Regional Research 33 (3):621-639.

Eizenberg, E. 2012. The changing meaning of community space: Two models of NGO management of community gardens in New York City. International Journal of Urban and Regional Research 36 (1):106-120.

Federici, S. 2004. Caliban and the Witch: Women, the Body and Primitive Accumulation 1st edition. New York; London: Autonomedia.

Finney, C. 2014. Black Faces, White Spaces: Reimagining the Relationship of African Americans to the Great Outdoors. Chapel Hill: The University of North Carolina Press.

Fraser, N. 2014. Can society be commodities all the way down? Post-Polanyian reflections on capitalist crisis. Economy and Society 43 (4):541-558.

Ghose, R., and M. Pettygrove. 2014. Actors and networks in urban community garden development. Geoforum 53:93-103.

Gibson-Graham, J. K. 2006. The End of Capitalism (As We Knew It): A Feminist Critique of Political Economy. Minneapolis: University of Minnesota Press.

Gilmore, R. W. 2002. Fatal couplings of power and difference: Notes on racism and geography. The Professional Geographer 54 (1):15-24.

Goodling, E. K., J. Green, and N. McClintock. 2015. Uneven development of the sustainable city: Shifting capital in Portland, Oregon. Urban Geography 36 (4):504-527.

Gould, K. A., and T. L. Lewis. 2016. Green Gentrification: Urban Sustainability and the Struggle for Environmental Justice. New York: Routledge.

Guthman, J. 2011. Weighing In: Obesity, Food Justice, and the Limits of Capitalism. Berkeley: University of California Press.

Hackworth, J. 2002. Postrecession gentrification in New York City. Urban Affairs Review 37 (6):815-843.

Harvey, D. 1989. The Urban Experience. Baltimore: The Johns Hopkins University Press.

Henderson, G. 1998. Nature and fictitious capital: The historical geography of an agrarian question. Antipode 30 (2):73-118.

Henson, Z., and G. Munsey. 2014. Race, culture, and practice: Segregation and local food in Birmingham, Alabama. Urban Geography 35 (7):998-1019.

Hern, M. 2016. What a City is For: Remaking the Politics of Displacement. Cambridge, MA: MIT Press.

Holt, S. 2015. An unexpected romance: urban farmers and real estate developers. CityLab. http://www.citylab.com/cityfixer/2015/10/the-newest-odd-couple-real-estate-developersand-urban-farmers/409060/ (last accessed 4 October 2016). 
Irazábal, C., and A. Punja. 2009. Cultivating just planning and legal institutions: A critical assessment of the South Central Farm struggle in Los Angeles. Journal of Urban Affairs $31(1): 1-23$.

Johnston, J., and S. Baumann. 2014. Foodies: Democracy and Distinction in the Gourmet Foodscape. New York: Routledge.

Jurjevich, J. R., and G. Schrock. 2012. Is Portland Really the Place Where Young People Go To Retire? Migration Patterns of Portland's Young and College-Educated, 1980-2010. Portland, OR: Population Research Center. http://pdxscholar.library.pdx.edu/prc_pub/5/ (last accessed 11 February 2015).

Knuth, S. 2016. Seeing green in San Francisco: City as resource frontier. Antipode 48 (3):626644.

Lave, R. 2012. Bridging political ecology and STS: A field analysis of the Rosgen Wars. Annals of the Association of American Geographers 102 (2):366-382.

Lawson, L. J. 2005. City Bountiful: A Century of Community Gardening. Berkeley: University of California Press.

Lebowitz, A., and D. Trudeau. 2016. Digging in: Lawn dissidents, performing sustainability, and landscapes of privilege. Social \& Cultural Geography doi: 10.1080/14649365.2016.1218041:1-26.

Lipsitz, G. 2007. The racialization of space and the spatialization of race: Theorizing the hidden architecture of landscape. Landscape Journal 26 (1):10-23.

Lubitow, A., and T. R. Miller. 2013. Contesting sustainability: Bikes, race, and politics in Portlandia. Environmental Justice 6 (4):121-126.

Marx, K. 1976. Capital: A Critique of Political Economy, Vol. 1. London: Penguin Classics.

McCann, E. 2013. Policy boosterism, policy mobilities, and the extrospective city. Urban Geography 34 (1):5-29.

McClintock, N. 2010. Why farm the city? Theorizing urban agriculture through a lens of metabolic rift. Cambridge Journal of Regions, Economy and Society 3 (2):191-207. . 2014. Radical, reformist, and garden-variety neoliberal: coming to terms with urban agriculture's contradictions. Local Environment 19 (2):147-171.

McClintock, N., D. Mahmoudi, M. Simpson, and J. P. Santos. 2016. Socio-spatial differentiation in the Sustainable City: A mixed-methods assessment of residential gardens in metropolitan Portland, Oregon, USA. Landscape and Urban Planning 148:1-16.

McClintock, N., and M. Simpson. 2016. Cultivating in Cascadia: Urban Agriculture Policy and Practice in Portland, Seattle, and Vancouver. In Cities of Farmers: Problems, Possibilities and Processes of Producing Food in Cities, eds. J. Dawson and A. Morales, 59-82. Iowa City: University of Iowa Press.

McDowell, L. 1999. Gender, Identity and Place: Understanding Feminist Geographies. Minneapolis: University of Minnesota Press.

McKittrick, K. 2006. Demonic Grounds: Black Women And the Cartographies of Struggle. Minneapolis: University of Minnesota Press. 2011. On plantations, prisons, and a black sense of place. Social \& Cultural Geography 12 (8):947-963.

Meehan, K., and K. Strauss eds. 2015. Precarious Worlds: Contested Geographies of Social Reproduction. Athens: University of Georgia Press.

Minkoff-Zern, L.-A. 2014. Hunger amidst plenty: farmworker food insecurity and coping strategies in California. Local Environment 19 (2):204-219. 
Mitchell, K., S. A. Marston, and C. Katz eds. 2004. Life's Work: Geographies of Social Reproduction. New York: Wiley.

Moore, D. S., A. Pandian, and J. Kosek eds. 2003. Race, Nature, and the Politics of Difference. Durham: Duke University Press.

National Gardening Association. 2014. Garden to Table: A 5-Year Look at Food Gardening in America. Williston, VT. http://goo.gl/lf4xSD (last accessed 23 June 2015).

Naylor, L. 2012. Hired gardens and the question of transgression: lawns, food gardens and the business of "alternative" food practice. Cultural Geographies 19 (4):483-504.

Pearsall, H. 2010. From brown to green? Assessing social vulnerability to environmental gentrification in New York City. Environment and Planning C: Government and Policy $28(5): 872-886$.

Pearsall, H., and I. Anguelovski. 2016. Contesting and resisting environmental gentrification: Responses to new paradoxes and challenges for urban environmental justice. Sociological Research Online 21 (3):1-6.

Postone, M. 1978. Necessity, labor, and time: A reinterpretation of the Marxian critique of capitalism. Social Research 45 (4):739-788.

Pudup, M. 2008. It takes a garden: Cultivating citizen-subjects in organized garden projects. Geoforum 39 (3):1228-1240.

Pulido, L. 2000. Rethinking environmental racism: White privilege and urban development in southern California. Annals of the Association of American Geographers 90 (1):12-40.

- 2016. Geographies of race and ethnicity II: Environmental racism, racial capitalism and state-sanctioned violence. Progress in Human Geography doi: 10.1177/0309132516646495:309132516646495:1-10.

Purcell, M., and S. K. Tyman. 2014. Cultivating food as a right to the city. Local Environment 20 (10):1132-1147.

Quastel, N. 2009. Political ecologies of gentrification. Urban Geography 30 (7):694-725.

Ramírez, M. M. 2015. The elusive inclusive: Black food geographies and racialized food spaces. Antipode 47 (3):748-769.

Renner, S. 2016. Top 10 cities in the U.S. for urban farming. inhabit. http://inhabitat.com/top-10cities-in-the-us-for-urban-farming/ (last accessed 17 November 2016).

Reynolds, K., and N. Cohen. 2016. Beyond the Kale: Urban Agriculture and Social Justice Activism in New York City. Athens: University of Georgia Press.

Robinson, C. J. 2000. Black Marxism: The Making of the Black Radical Tradition 2nd ed. Chapel Hill: The University of North Carolina Press.

Rosol, M. 2013. Vancouver's "EcoDensity" planning initiative: A struggle over hegemony? Urban Studies 50 (11):2238-2255.

Safransky, S. 2014. Greening the urban frontier: Race, property, and resettlement in Detroit. Geoforum 56:237-248.

- 2016. Rethinking land struggle in the postindustrial city. Antipode doi: 10.1111/anti.12225:1-22.

Sbicca, J. 2016. These bars can't hold us back: Plowing incarcerated geographies with restorative food justice. Antipode 48 (5):1359-1379.

Schmelzkopf, K. 2002. Incommensurability, land use, and the right to space: Community gardens in New York City. Urban Geography 23 (4):323-343.

Slater, T. 2006. The eviction of critical perspectives from gentrification research. International Journal of Urban and Regional Research 30 (4):737-757. 
Slocum, R. 2007. Whiteness, space and alternative food practices. Geoforum 38:520-533.

Smith, D. M. 2012. Breaking: Portland sustainability chief admits "Portlandia" isn't really a parody. Grist. http://grist.org/cities/breaking-portland-sustainability-chief-admitsportlandia-isnt-really-a-parody/ (last accessed 17 November 2016).

Smith, N. 1979. Toward a theory of gentrification: A back to the city movement by capital, not people. Journal of the American Planning Association 45 (4):538-548.

- 1996. The New Urban Frontier: Gentrification and the Ravanchist City. London: Routledge.

- 2008. Uneven Development: Nature, Capital, and the Production of Space. Athens: University of Georgia Press.

Staeheli, L. A., D. Mitchell, and K. Gibson. 2002. Conflicting rights to the city in New York's community gardens. GeoJournal 58 (2/3):197-205.

Stehlin, J. 2016. The post-industrial "shopfloor": Emerging forms of gentrification in San Francisco's innovation economy. Antipode 48 (2):474-493.

Stehlin, J. G., and A. R. Tarr. 2016. Think regionally, act locally?: gardening, cycling, and the horizon of urban spatial politics. Urban Geography doi:10.1080/02723638.2016.1232464:1-23.

Tarr, A. R. 2015. Have Your City and Eat It Too: Los Angeles and the Urban Food Renaissance. $\mathrm{PhD}$ dissertation, University of California, Berkeley.

Walker, R. 1978. Two sources of uneven development under advanced capitalism: Spatial differentiation and capital mobility. Review of Radical Political Economics 10 (3):28-37.

Walker, S. 2016. Urban agriculture and the sustainability fix in Vancouver and Detroit. Urban Geography 37(2):163-182.

Weissman, E. 2015. Brooklyn's agrarian questions. Renewable Agriculture and Food Systems 30 (1):92-102.

While, A., A. E. G. Jonas, and D. Gibbs. 2004. The environment and the entrepreneurial city: searching for the urban "sustainability fix" in Manchester and Leeds. International Journal of Urban and Regional Research 28 (3):549-569.

White, M. M. 2011. Sisters of the soil: Urban gardening as resistance in Detroit. Race/Ethnicity: Multidisciplinary Global Contexts 5 (1):13-28.

Woods, C. 2000. Development Arrested: The Blues and Plantation Power in the Mississippi Delta. London: Verso.

Zillow. 2016. http://www.zillow.com (last accessed 23 November 2016).

Zukin, S. 1987. Gentrification: Culture and capital in the urban core. Annual Review of Sociology 13:129-147.

NATHAN McCLINTOCK is an Assistant Professor in the Toulan School of Urban Studies and Planning at Portland State University, Portland, OR 97207.E-mail: n.mcclintock@pdx.edu. His research interests include urban political ecology, critical urbanism, and food systems planning. 